\title{
Building networks among info pros
}
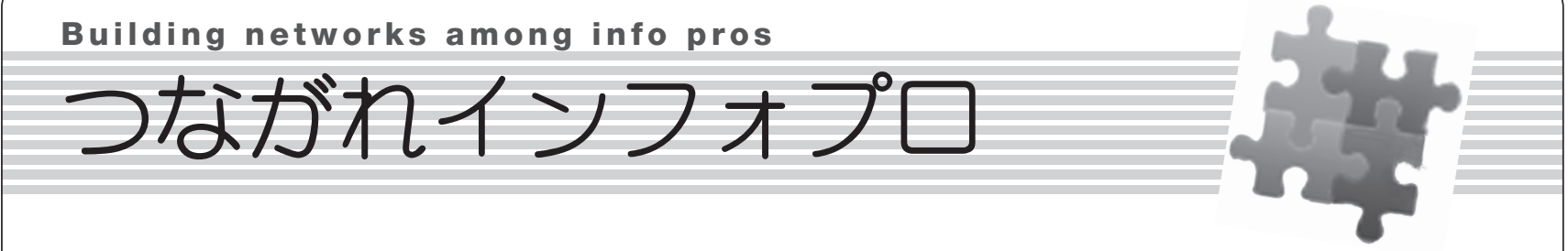

第 21 回

柴田祥衣（京都府立図書館）

情報管理. 2015, vol. 58, no. 4, p. 306-308. doi: http://dx.doi.org/10.1241/johokanri.58.306

\section{ししょまろはんとは}

「ししょまろはん」注1）とは，主に京都府立図書館 で働く図書館司書で構成された業務外の自主学習グ ループである。代表の是住久美子の呼び掛けによっ て2013年6月に結成され，現在は16人が所属してい る。当初は京都府立図書館の正規職員亡非常勤嘱託 職員のみがほぼ同数所属していたが，現在は国立国 会図書館関西館や京都府内の学校図書館に勤務する 者もメンバーとなっている。

活動日や活動場所は，明確に固定されてはいない。 話し合いたい議題や目新しい情報があればメーリン グリストで共有され，それぞれのメンバーが必要に 応じて集まりを呼び掛ける。昼休みや終業後など， ごく気軽に集まりが開催できるのは，メンバーの多 くが同じ職場にいるグループならではの利点だろう。

発足理念についても確固たるものがあるとは聞い ていないが，メンバーの1人である筆者としては，「京 都の司書が集まって，みんなの役に立ってうちらの
勉強にもなる面白いこと，できひんかな？」という ようなものだと理解している。自主学習グループと 名乗ってはいるものの，勉強やディスカッションの 場というよりは，個々の「できひんかな?」を「やっ てみよ!」にする実験の場としての意味合いが大き い。実際の活動からそれぞれが学び，そして得た知 見を共有することで，結果的に司書としての研鑽が 行われている。

メンバーによって活動へのかかわり方もまったく 異なり，後述の「京都が出てくる本のデータ」のた めにひたすら本を読んでデータを作成する者，図書 館やオープンデータに関係するイベントに参加して 情報収集を行う者，Twitterなどを利用してWebでの 発信を行う者（図1），デザインや広報を担当する者 など，個々の関心や能力を生かして活動を行ってい る。現在も，ししょまろはんの中ではいくつかの活 動が行われ，また企図されているが，本稿ではその 中でも核となっている3つの活動を紹介したい。

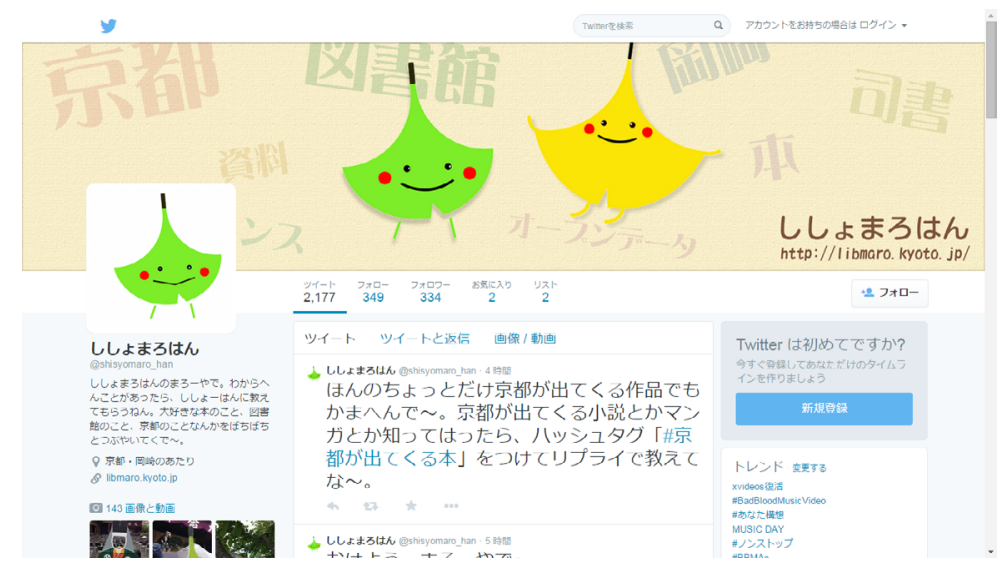

図1 ししょまろはんTwitter https://twitter.com/shisyomaro_han 


\section{京都が出てくる本のデータ}

丸善には橏檬が置かれ，鴨川デルタではホルモ一 が行われ，至るところで殺人事件が発生するのが， 小説の中で描かれる京都である。ししょまろはんで は，京都が舞台になっている小説や漫画等のデータ を作成し，「京都が出てくる本のデータ」注2）として 公開している。メンバーが実際に京都の登場する本 を読み（図2），図書の書誌，作品に出てくる土地の 位置データ，お勧め度や内容の簡単な紹介文，さら にWeb NDL Authorities注3) の著者名の典拠URIを加え て作成している。データはししょまろはんメンバー 共有のGoogleスプレッドシートに蓄積し，メンバー の誰もが気軽に編集できるようになっている。

「京都が出てくる本のデータ」はLinkData.org注4) の 機能を用いてRDF形式に変換し，クリエイティブ・コ モンズライセンスCC-BY（著作権表示を主な条件とし て，改変や営利目的での二次利用も許可する）でオ一 プンデータとして公開している。現在1,200回以上ダ ウンロードされ，スマートフォン用アプリ「ご当地 なび」注5) のコンテンツとしても組み入れられた。し しょまろはんには今のところアプリを開発できるよ うなメンバーはいないが，作成したデータをオープ ンデータとして公開することによって，より多くの 人々にアプリという形でデータが活用されることと なった。このような広がりは，まさにオープンデー

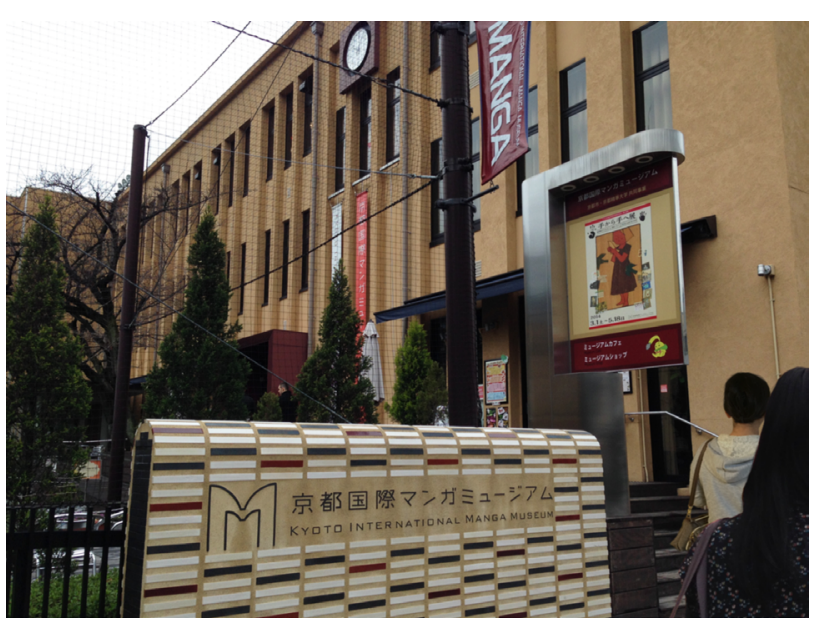

図2「京都国際マンガミュージアム」で 京都が出てくる漫画を探すメンバー
タの長所と可能性を示しているといえよう。

\section{京都レファレンスマップ}

ししょまろはんが作成しているもう1つのオープン データがある。それが「図書館員が調べた京都のギ モン 京都レファレンスマップ」注6) である。国立国 会図書館の「レファレンス協同データベース」に蓄 積されたデータの中から京都に関する事例をピック アップして，URLと質問文を引用し，位置情報等を付 与してデータを作成している。

たとえばパソコンやスマートフォンでその地図を 開くと（図3），あちこちにピンが立っている。その 中から京都御苑に立つピンをクリックすると，「明治 初期に京都御所内にあった京都博物館について知り たい」という文などが掲載されたタグが表示される。 御所の中に博物館があったの? と，さらにタグ内 のDB-URLをクリックしてみると，1875（明治8）年 4月に京都府営の博物館が京都御所の旧米蔵を借りて 開館していたこと，約8年で閉館してしまったが，所 蔵品が現在の京都国立博物館に引き継がれているこ と，その歴史がどういった資料に記されているかな どがわかる。

\section{京都まち歩きオープンデータソンへの協力}

「まち歩きオープンデータソン」とは，参加者が史 跡や観光スポットを歩き，得た情報をオープンデー タにするイベントで，本連載の第18回（情報管理. vol. 57,no. 12) で日下九八さんが紹介している「ウィ キペディアタウン」注7) と，フリーの地理情報データ を作成する「OpenStreetMapマッピングパーティー」 を組み合わせたものである。ししょまろはんは京都 で開催されるこれらのイベントで，図書館での地域 情報の調べ方の案内，著作権についてのレクチャー， 関連資料の提供などを行っている。

おわりに

京都府立図書館の入り口付近にあるベンチを見て， 


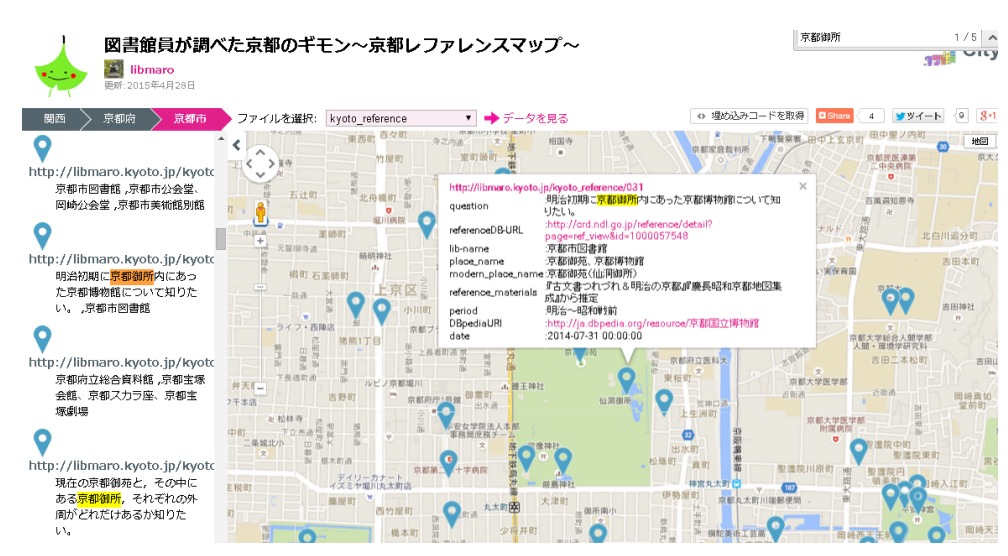

図3 京都レファレンスマップ

目を輝かせてはしやぐ人々がいる。その人々の目に 映っているのは，ありふれた青いベンチではなく， アニメ『けいおん!!』のキャラクターが座り，話し， ドラマを繰り広げたベンチだ。創作作品のファンが 作品に関係する土地を探訪する一いわゆる「聖地 巡礼」をしている人々は，みな，とても生き生きと している。

聖地巡礼に限つたことではない。ある知識を得る ことによって，毎日のように通っている道が，いつ も何気なく目に入っているはずの風景が，急に豊か な色彩を帯びて見え始めることがある。情報によつ て土地が物語をもち，意味をもつ。土地自体には何 の変化もなくとも，知ることによって見る目が変わ り，そこに価值とさらなる興味が生まれる。興味と は「もつとそれについて情報を得たい」という感情で， 情報を求める人々をサポートするのは，まさにイン
フォプロの本分であろう。「京都が出てくる本のデー タ」も，「京都レファレンスマップ」も，「まち歩きオー プンデータソン」への協力も，ある情報と土地とを つなぎ合わせてそのデータを発信し，世界と共有す る試みといえる。私たちは「情報の需要」を探すだ けでなく，発信することで自らそれを作り出すこと もできるのだ。

知識を得て，興味をもつことで，私たちが生きる 世界はもつと輝いて見え始める。ししょまろはんの 活動が，その一助となることを願つている。

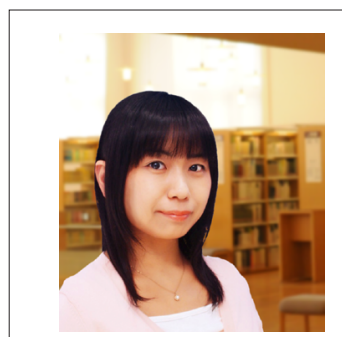

柴田 祥衣（しばた さちえ）

ししょまろはんメンバー。京 都府立総合資料館歴史資料課を 経て，京都府立図書館に勤務。 現在は新聞に関するレファレン ス等の業務を行っている。

\section{本文の注}

注1）ししょまろはんラボ. http://libmaro.kyoto.jp/

注2） 京都が出てくる本のデータ.http://linkdata.org/work/rdf1s1294i

注3) Web NDL Authorities. http://id.ndl.go.jp/auth/ndla

注4) LinkData.org. http://linkdata.org/

注5）ご当地なび. https://itunes.apple.com/jp/app/id398326620

注6) 図書館員が調べた京都のギモン 京都レファレンスマップ.http://linkdata.org/work/rdf1s1534i

注7) 日本で開催されたウィキペディアタウンのアーカイブ http://ja.wikipedia.org/wiki/プロジェクト:アウトリーチ/ウィキペディアタウン/アーカイブ 